\title{
日本·カナダ P
}

\section{女性研究者}

\section{日本・カナダ女性侀究者 \\ 交流事業参加ホポート1}

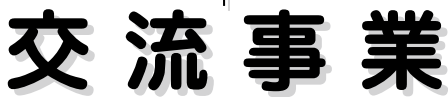

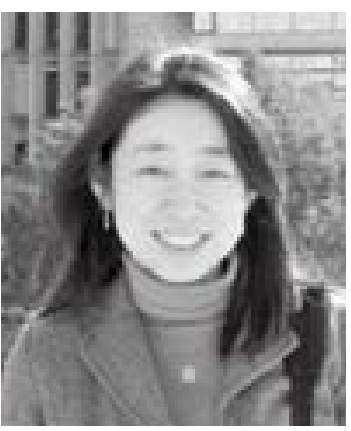

小溧有京

鹿児島大学生涯学習教育研究セン ター准教授

専門：環境教育、社会教育、持続 可能な開発と地域教育論

\section{1はじめに}

このたび、日本学術会議とカナダ王立協会が共 同で実施する平成 21 年度日本・カナダ女性研究者 交流事業により、平成 22 年 3 月 16 日から 25 日の日 程でカナダに派遣された。渡航にあたり、私には 二つの目的があった。一つは、カナダの環境教育 研究における先住民社会とのかかわりについて最 新動向をつかみ、研究が生み出されるカナダ社会 について見聞を広めることであった。もう一つは、 今後の研究のために人的ネットワークをつくるこ とであった。わずかな滞在期間であったが、訪問 した先々で、大学教員や職員、学生、教師、児童 生徒など多様な方々と意見を交わす機会に恵まれ、 驚きと発見の多い、濃密な時間を過ごすことがで きた。その概要について報告させていただく。

\section{2 訪問先と光の概要}

今回訪問したのは、飛行機で $4 \sim 5$ 時間離れた 二つの街である。前半 (3月 16 日 (夜着) 〜 20 日 (朝 発)）は、五大湖の一番東に位置するオンタリオ湖 北部の街、オンタリオ州ピーターバラ市のTrent Universityを基点とした車で 2 時間圈内の大学と 研究機関を訪れた。後半 (3月20日（夕方着）〜 24 日（朝発)）は、ロッキー山脈の東側の麓に位 置するアルバータ州カルガリー市のUniversity of Calgary と中学校を訪問した。前半は、トレント大 学の Daniel Roronhiakewen Longboat教授、後半は、 カルガリー大学 Ph.D Candidate の Greg Lowen 氏 にホスト役を引き受けていただき、滞在期間の訪 問先などの一切をコーディネートしていただいた。

このお二方は、実は前年度に参加した第5回国 際環境教育会議（開催地：カナダ・モントリオー ル）の「先住民の知恵と実践」分科会で知り合っ た研究者らだった。この会議は、1996年に創立し たCanadian Network for Environmental Education and Communication（EECOM）の年次大会と合同 で開催されたもので、私にとって、カナダの環境 教育研究に先住民研究が梁くかかわっている事実 を確認する貴重な機会となった。

他の欧米諸国の環境教育研究に比べカナダは、 


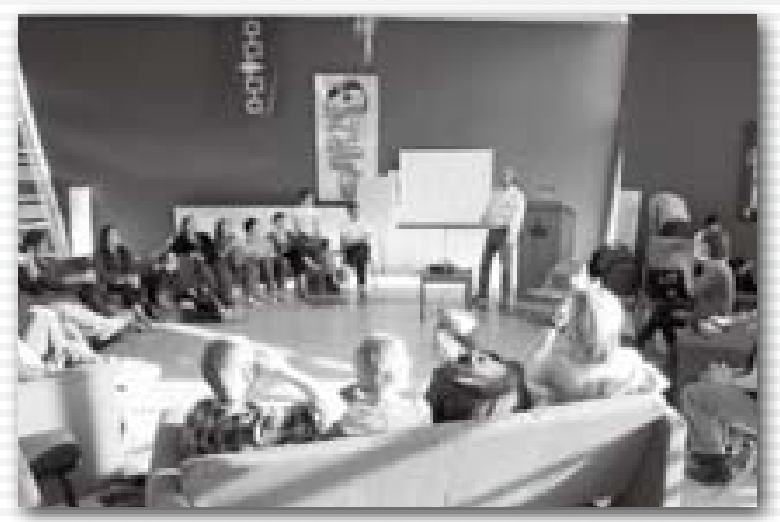

写真 1 ：Indigenous Food Celebrationに集まった教員、 学生、市民。これから小栗の講義が始まる。

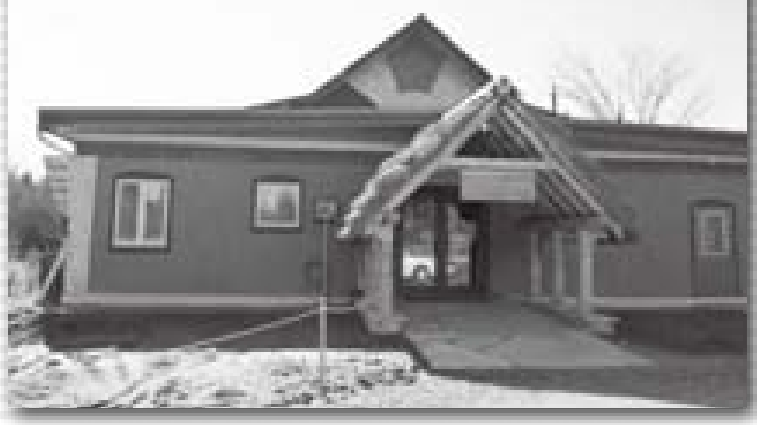

写真 2：Trent University と Sir Sandford Fleming College が共同で取り組む Sustainable Building。太陽光、 雨水利用、ストローベール建築、屋根上緑化など 環境技術について体験学習できる施設。
西洋的世界観や科学知識の相対化を試みる研究に 個性がみられる。私はかねてより、その課題設定 が、日本の農山漁村の暮らしが育んだ自然観や知 恵、技能を現代的課題の解決に生かそうとする私 の研究関心と重なり、関心を寄せていた。

そして、実際に課題意識を共有する研究者らと 出会い、日本とは風土や歴史が全く異なるカナダ における研究が、いかなる社会状況を背景とし、 それが今どこへ向かおうとしているのか、この目 で確かめたい。日本の経験や研究の交流が、双方 を高めあうことになるのではないかといった動機 に導かれ、彼らのホームキャンパスに向かった。

以下に、各々の訪問先の概略を記す。

\section{前半 : オンタリオ州ピーターバラ市周辺}

(1) Trent University, Indigenous Studies and

\section{Indigenous Environmental Studies Program}

Longboat教授が勤めるトレント大学では、17日 から19日にかけて、キャンパスッアーに始まり、 彼が所属する先住民学専攻の他の教員や職員、学 生をたくさん紹介いただき、当専攻の特徴を知る ことができた。18日の夕方は、先住民環境研究が 主催するIndigenous Food Celebrationに招かれ、 教員や学生、市民に向けて初めて講演する機会を 得た（写真1）。学生による先住民劇の発表もあり、 大きな異文化交流の機会となった。
Indigenous Environmental Studies Program は、 Longboat教授がカナダで初めてと自負するプログ ラムで、彼の修士論文と博士論文をべースに開発 され、先住民の知識や価値と西洋科学のそれとを 統合（知識システムの統合）することを目指す。 二つの考え方を融合することで、物事の理解や見 方をより幅あるものにすることが狙いだ。1999年 から開始したプログラムに、環境学や先住民学な ど異なる専攻の学生 150 名以上が学び、今では先 住民環境研究の学士を出せるまでになっている。

\section{(2) Sir Sandford Fleming College}

17日の午後にSir Sandford Fleming Collegeで 講演する予定だったが、訪問先の都合（教授が急 病）で急遽中止になった。代わりに、トレント大 学の敷地内にあるSir Sandford Fleming College と 共同で取り組むSustainable Building Design and Construction Programの施設を見学した（写真 2)。 Longboat教授によると、カナダの college は実学に 力点をおき、実践的知識の習得を得意とするとい う。アカデミックな教育を重視する universityには 欠けている部分であるため、兩者がコースを提供し あうことで、地域社会や学生のニーズに一層応えら れるプログラムの開発を進めているとのことで、そ れを今回見せたかったと教授は語っていた。

\section{(3) Tyendinaga First Nations Technical Institute}

18日の日中は、Tyendinaga Mohawk先住民 


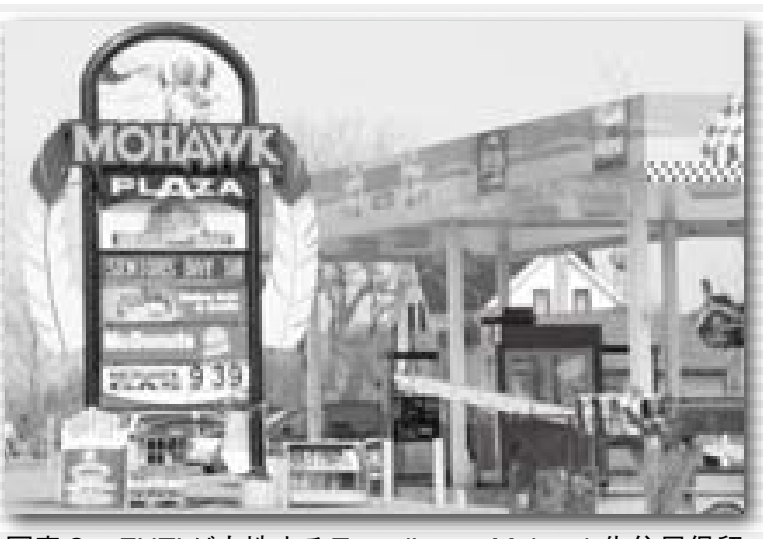

写真 3：FNTIが立地する Tyendinaga Mohawk先住民保留 地。Longboat教授の出身コミュニティでもある。

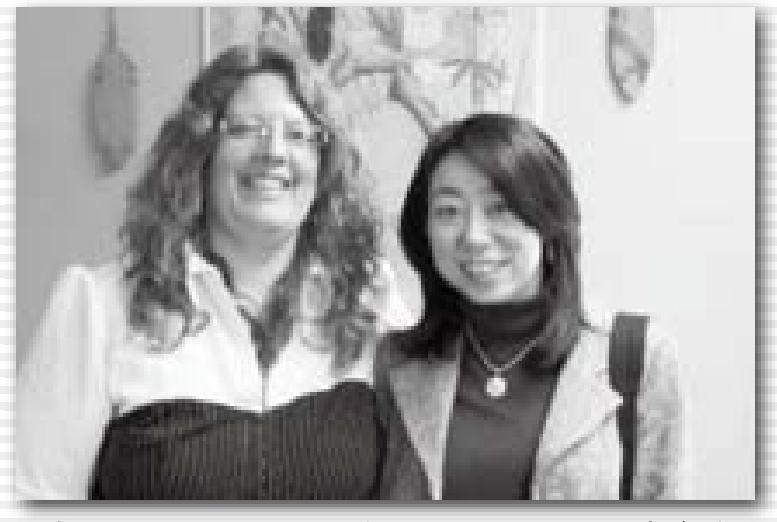

写真 4 : Suzanne BrantマネージャーとFNTIの事務所に おいて、彼女もMohawkコミュニティの出身。
保留地内にある First Nations Technical Institute （FNTI）を訪問し（トレント大学から車で2時間）、 先住民の健康と伝統的な薬に関するプログラムを 住民に提供するSuzanne Brantマネージャーとそ のスタッフらと意見交換を行った（写真3、4）。 1985年に設立したFNTIは、先住民が所有し、管 理するカナダ社会では先駆的な教育研究機関であ る。話を伺ったプログラムは、伝統的な食生活の 変容による先住民の 5 大病（糖尿病、心臓発作、 ガンなど）を薬で治療する政策に対抗し、食生活 を見直すことで、病を根本から断つことを目指し ていた。独自で研究を進める傍ら、複数の大学が 協力する体制を確立していた。

\section{(4) York University, Masters Program in}

\section{Environmental Studies}

最終日は、トロント市（トレント大学から車で 1 時間半）にあるYork University 環境学の修士課 程の授業で講義を行った。この授業は、先住民社 会の問題に理解があり、Longboat教授と親しい環 境教育研究者のLeesa Fawcett教授の「野生生物 と人間」のクラスであった。Longboat教授は、自 らを環境教育の専門家とはみなさない。ゆえにす ばらしい教師がいると、わざわざ足を延ばして Fawceett教授と引き合わせてくれた（写真5）。

\section{後半 : アルバータ州カルガリー市周辺}

\section{(1) Hike to Grotto Creek Trail}

カルガリー市に到着した翌日21日（日）は、 Greg 夫妻に先住民の古代壁画が残る Grotto Creek Trail(ロッキー山脈国立公園内)に案内いただいた。 市内から西へ車で走ること 2 時間弱、途中Stoney 先住民保留地を抜け、山間にそびえたつ鉱物精錬 工場をいくつか目撃した。ハイキング道にも並行 して轟音をたてるマグネスウムの精錬工場があり (写真6)、先住民の壁画のすぐ横には、ロッククラ イミング愛好者用の金具が埋め込んであった。そ のコントラストの中に、カナダの歴史と現状をみ るようで忘れられない光景となった。

\section{(2) University of Calgary, Faculty of Environment}

石油開発を背景に急速に経済成長を遂げるカル ガリー市にあるカルガリー大学は、街の膨張とと もに大学も建設ラッシュが続く。この大学で 22 日、 大学教員（主に教育学部）や職員、日本にゆか りのある市民が出席するなか講演を行った。日本 の農村過疎問題に対して、成人教育、芸術、ビジ ネスなど多様な方面から質疑を受け、奥行き深い 時間となった。Greg氏の指導教官である Patricia （Gail）Jardine教授ともそこでお会いした。

Jardine教授は、先住民研究と環境教育研究の両 方を専門にする数少ない教授だと Greg 氏はいう。 Siksika先住民社会で非先住民の教師としてキャリ 


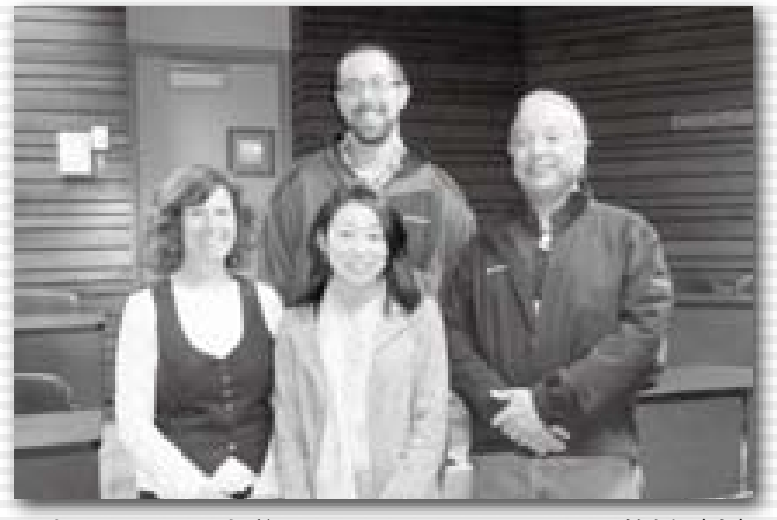

写真 5：ヨーク大学において、Leesa Fawcett教授（左） とDr. Longboat 教授（右）。

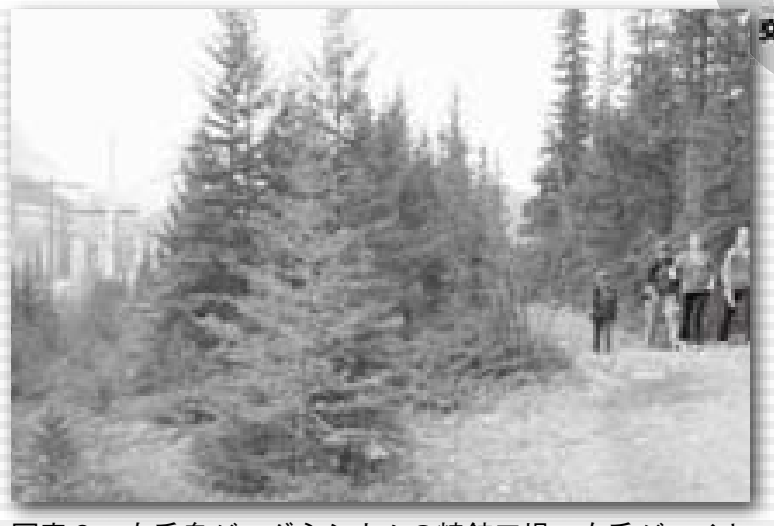

写真 6 ：左手奥がマグネシウムの精錬工場、右手がハイキ ングトレール。
アを積み、今は大学の教壇に立つ彼女の関心は、 先住民とヨーロッパの関係で、特に先住民の教 師教育に力を入れる。私が講演中に触れたカナダ Grassynarrowの事例（水俣病問題の発生による先 住民社会の退廃）は氷山の一角で、どこも環境問 題はひどい。主な問題は麻薬と缶で、その背景に 貧困と伝統が継承されてこなかったことを指摘す る彼女は、コミュニティに染く入り込むことを大 事にしていた。

昨年の国際環境教育会議で先住民の分科会を 任されていたGreg氏は、環境教育研究が熱心な Lakehead大学で修士号を取得している。そんな彼 が、環境教育コースのないカルガリー大学に移っ てきたのはJardine教授がいたからだ。彼は、先住 民とヨーロッパ人の混血（metis（メイティ）とい う）で、ヨーロッパ人が先住民を征服する以前の 友好関係の時代にこそ、カナダ国の起源があると 考え、そのメイティの哲学、すなわち “ecological metissage”の提唱（研究）に取り組む。異なる文 化の考え方を環境教育にどう統合していくのかに 彼の関心はあった。

\section{(3) Sir John A. MacDonald Jr. High School}

最終日は、2 回に分けて中学生4クラスに講義を 行った（写真7）。私の問いかけに積極的に答えて くれる生徒は、バンクラディッシュ、スリランカ、 韓国、中国と国籍は実に様々で、多民族国家の姿
が日常の学校生活そのものだった。日本の事例を 生徒目線に置き換えるRyan Duplassiesi教師（写 真8）の見事な進行で、狩猟はしても、肉になる過 程にはかかわりたくない生徒の生の声や、子ども の自然体験が圧倒的に不足していると語る同僚教 師の悩みなど、日本にも似た子供たちの生活実態 を確認することができた。

\section{3 おわりに}

以上が、今回体験し、感じたことのごく一部で ある。何よりも、現地に足を踏み入れなければ決 してつかめない、カナダの自然と社会風土を肌感 覚として得られた訪問となった。目的として臨ん だことにも期待以上の収穫があった。

まず、今回の交流により、長い先住民と西洋の 文化の対立と闘争が、まだ多くの社会問題を残す ものの、ここ 30 年の運動と研究の成果でずいぶん 前進したこと、また、環境問題の複雑さが明るみ になるに伴い、先住民社会の考え方や知識に答え を求める、社会の意識的高揚が生まれつつあるこ とを知った。

今回意見を交わした、先住民、メイティ（混血）、 非先住民と出自の異なる研究者は、それぞれ異な る動機で同じ社会問題に立ち向かっていた。特徵 


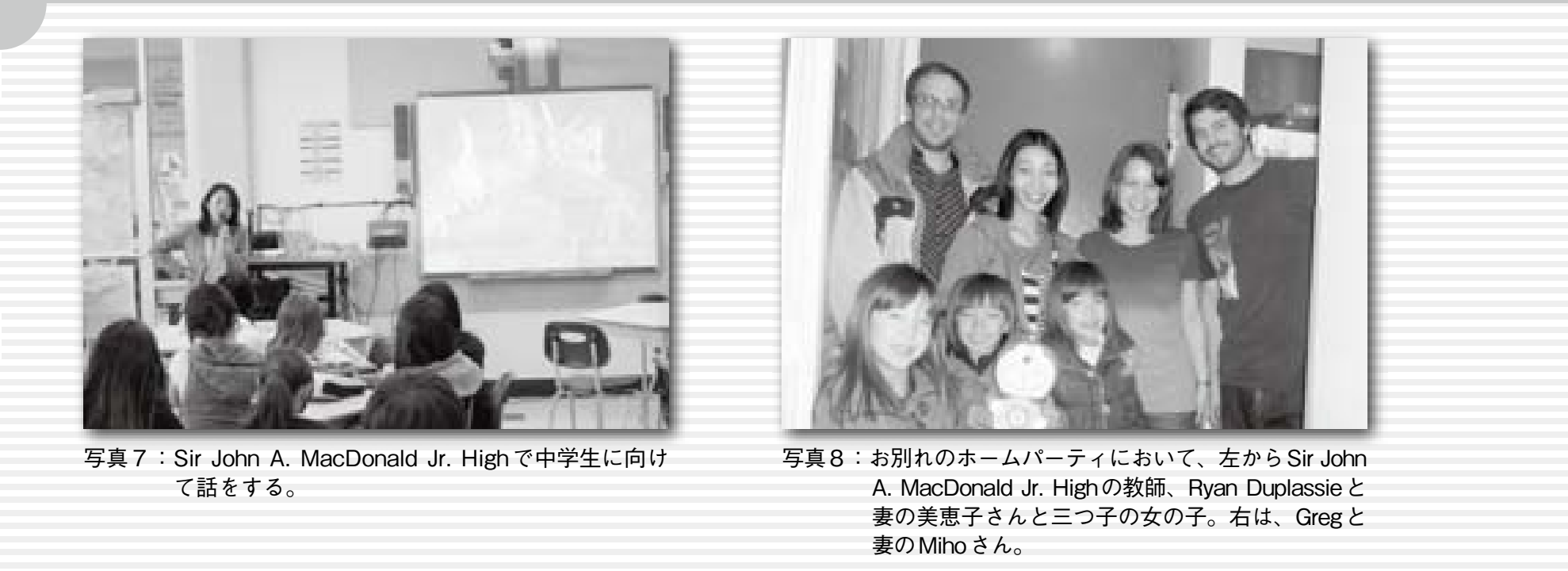

は、先住民か西洋かという二項対立ではなく、例 えば、Longboat教授が強調する「先住民、企業、 環境の win-win-win の実現を助ける教育」であった り、Greg氏の「先住民と西洋人の融和の哲学（メ イティ哲学)」といった、問題を異なる考え方や知 識を統合して解いていける人の育成にあった。

今回の渡航をきっかけに、カナダ成人教育学会 への参加の誘いを受けたり、Greg氏と共著でカ ナダの環境教育ジャーナルに投稿する企画がまと まったり、人的ネットワークにも早くも芽が出始 めている。

また、予期しない驚きとしては、私の研究のエッ センスでもあった、水俣市の再生に生きた水俣病 患者の言葉に対して、日本では経験しない深い共 感を先住民研究者から得たことだった。日本とカ ナダを貫く普遍的なものの存在に手ごたえを感じ る出来事であった。今年の秋には、再びカナダに 戻ることを計画しており、今回の経験をぜひ次へ とつなげていきたい。

\section{謝辞}

今回このような機会を提供いただいた日本学術 会議とカナダ王立協会の皆様に心より感謝してお ります。渡航手続きの関係では、日本学術会議事 務局の鈴木健太郎氏とカナダ王立協会の Courtney Bull氏には、多大なご支援を賜りました。Daniel
Roronhiakewen Longboat教授と Greg Lowen氏に は、滞在期間はもちろんのこと、渡航前から多く の時間と労力を割いていただき本当にお世話にな りました。他にも訪問した先々でお会いした方々 や、影で今回の渡航を支えてくださった皆様方に、 この場を借りて厚く御礼申し上げます。 